Juan Emilio Fernández-

Barbero

Pablo Galindo-Moreno

Gustavo Ávila-Ortiz

Octavio Caba

E. Sánchez-Fernández

Hom-Lay Wang

\section{Flow cytometric and morphological characterization of platelet-rich plasma gel}

Authors' affiliations:

Juan Emilio Fernández-Barbero, Octavio Caba, Human Anatomy and Embryology Department, School of Medicine, University of Granada, Granada, Spain

Pablo Galindo-Moreno, Gustavo Ávila-Ortiz, Sánchez-Fernández, Oral Surgery Department, School of Dentistry, University of Granada, Granada, Spain

Hom-Lay Wang, Department of Periodontics/ Prevention/Geriatrics, School of Dentistry,

University of Michigan, Ann Arbor, MI, USA

\section{Correspondence to:}

Pablo Galindo-Moreno

C/Recogidas, $395^{\circ} \mathrm{Izq}$, I 8005

Granada

Spain

Tel.: + 34958520658

e-mail: pgalindo@ugr.es
Date:

Accepted I 5 February 2005

To cite this article:

Fernández-Barbero JE, Galindo-Moreno P, Ávila-Ortiz G, Caba O, Sánchez-Fernández E, Wang H-L. Flow cytometric and morphological characterization of platelet-rich plasma gel.

Clin. Oral Impl. Res. I7, 2006; 687-693

doi: I0. I I I I/j. I600-050I.2006.0 I I 79.X

Key words: growth factors, platelet-rich plasma (PRP), tissue engineering, wound healing

\begin{abstract}
Background of problems: Platelet-rich plasma (PRP) gel is derived from an autogenous preparation of concentrated platelets and is widely used in implant dentistry as a vector for cell growth factors. However, limited data are available on its structure and composition. The present study was aimed at providing a flow cytometric and ultrastructural characterization of PRP gel.
\end{abstract}

Materials and methods: Twenty PRP gel samples were obtained from healthy volunteers. These PRP gel specimens were prepared for transmission (TEM) and scanning electron microscopy (SEM) examination of their morphological ultrastructure. Flow cytometry with CD41-PE monoclonal antibody was used to detect platelet cells, as this antibody recognizes human-platelet-specific antigen CD41.

Results: Both SEM and TEM showed that PRP gel contains two components: a fibrillar material with striated band similar to fibrin filaments, and a cellular component that contains human platelet cells. Both techniques indicated that no morphological elements were bound between the cellular component and the fibrillar material. The cells were confirmed as platelet cells by flow cytometric study after incubation with specific monoclonal antibody CD41-PE.

Conclusion: PRP gel contains a fibrillar and a cellular (largely human platelet cell) component. This unique structure may be capable of acting as a vehicle for carrying of cells that are essential for soft/hard tissue regeneration.

Platelet-rich plasma (PRP) is defined as a platelet pool found in non-coagulated and centrifuged blood (Marx et al. I 998). PRP is widely used to enhance tissue regeneration, especially after oral and maxillofacial surgery (Froum et al. 2002; Lekovic 2002, 2003; Della Valle 2003; Jakse et al. 2003; Maiorana et al. 2003; Sánchez et al. 2003; Wiltfang et al. 2003; Fennis et al. 2004; Thorn et al. 2004), based on the premise that autogenous PRP contributes large quantities of mitogenic polypeptides such as platelet derived growth factor (PDGF), transforming growth factor- $\beta$ (TGF- $\beta$ ), vascular endothelial growth factor and others, thereby enhancing osteogenesis (Marx et al. I998; Anitua I999; Schmitz \& Hollinger 200I; Okuda et al. 2003). However, controversy remains over its possible oncogenic role (Schmitz \& Hollinger 200I), and some authors have even questioned its activity in osseous-epithelial regeneration (Soffer et al. 2003; Weibrich et al. 2003a, 2003b; Arpornmaeklong 2004; Choi et al. 2004; Roldán et al. 2004).

Various protocols have been used to obtain PRP, but many of these techniques have been criticized for their inability to obtain an adequate concentration of platelets (Anitua I999; Marx 200I; Gonshor 
2002). Clinically, it is difficult to apply PRP as a mere pellet after the centrifugation of whole blood, because it lacks cohesion, hence it is difficult to maintain the platelet concentrate in the desired surgical site. As a result, many researchers have obtained a PRP gel by incubating the centrifuged material with calcium chloride, trapping these cell elements for the subsequent release of growth factors involved in osseous-epithelial regeneration (Anitua 200I). However, limited information is currently available on the elements that constitute PRP gel or their possible interactions. Therefore, the aim of the present study was to use electronic techniques to study the morphological structure of PRP gel and to analyze the interactions among the constitutive elements visualized.

\section{Material and methods}

\section{Preparation of PRP}

Venous blood was obtained from healthy volunteers who gave their informed consent and who had taken no medications for at least 2 weeks. To minimize platelet activation during blood collection, a I9-gauge butterfly needle with a light tourniquet was used and the first $2 \mathrm{ml}$ of blood was discarded. The procedure proposed by Anitua (1999) was followed to produce the PRP gel. Briefly after drawing $20 \mathrm{~cm}^{3}$ of blood, it was placed into four tubes, of $5 \mathrm{~cm}^{3}$ each one, that contains O.I volume of $3.8 \%(\mathrm{w} / \mathrm{v})$ sodium citrate. These tubes were then placed in a centrifuge machine to spin at I500 r.p.m. for $6 \mathrm{~min}$ in order to separate the blood fractions. The top of the red fraction was collected and $0.05 \mathrm{~cm}^{3}$ of calcium chloride was added for each $0.5 \mathrm{~cm}^{3}$ of plasma. Finally, the tubes were placed in $37^{\circ} \mathrm{C}$ warm water for $20 \mathrm{~min}$ to produce PRP gel.

\section{Monoclonal antibody}

$\mathrm{CD}_{4} \mathrm{I}-\mathrm{PE}$, purchased from Caltag Laboratories (Burlingame, CA, USA), a mouse monoclonal antibody to human-plateletspecific antigen $\mathrm{CD}_{4} \mathrm{I} \quad[/ \mathrm{Gp} \amalg \mathrm{a}-\mathrm{III} \mathrm{b}$ $\left.\left(\mathrm{a}_{\mathrm{Ir}} \mathrm{B}_{3}\right)\right]$, was used to detect and confirm the presence of platelet cells in PRP.

\section{Flow cytometric analysis (FACScan)}

Briefly, IO $^{5}$ platelet cells were transferred to universal screw cap tubes containing sterile PBS, then washed and centrifuged at $225 \mathrm{~g}$ for $5 \mathrm{~min}$, discarding the supernatant. The washing and centrifugation steps were then repeated. Cells were permeabilized with methanol for romin, washed three times in PBS, and once in distilled water. These cells were incubated for $30 \mathrm{~min}$ at $4^{\circ} \mathrm{C}$ with the monoclonal antibodies. They were then washed twice in cold PBS and re-incubated with FITCconjugated anti-mouse IgG (I:50) for FACScan analysis (Becton Dickinson, Mountain View, CA, USA).

\section{Transmission electron microscope (TEM) analysis}

Twenty PRP concentrate gels obtained were processed for electron microscopic study as described by Fernández et al. (1998). Briefly, they were fixed in situ with $2.5 \%$ glutaraldehyde in o. I M sodium cacodylate buffer $(\mathrm{pH} 7.4)$ for I h at room temperature. The gel was post-fixed with I \% osmium tetroxide in o. I M cacodylate buffer for $\mathrm{I} h$ at room temperature, dehydrated in ethanol, then detached from the culture vessel by rapid treatment in propylene oxide and embedded in Epon 8I2. After polymerization, the plastic was removed and ultrathin sections were cut parallel and perpendicular to the surface of the flask. The ultrathin sections were stained with uranyl acetate-lead citrate and examined by a Hitachi H 7000 TEM (Hitachi Ltd, Tokyo, Japan).

\section{Scanning electron microscopy (SEM) analysis}

Twenty gel samples were immediately immersed in a sodium cacodylate-buffered formaldehyde-glutaraldehyde fixative for $24 \mathrm{~h}$ at room temperature and post-fixed in $20 \%$ osmium tetroxide for $2 \mathrm{~h}$. Subsequently, samples were dehydrated by serial transfers in ascending concentrations of acetone (50-100\%) and infiltrated with liquid carbon dioxide before the critical drying point. Finally, the samples were made electrically conductive by mounting on aluminum slabs with a silver point, followed by sputter coating with gold/palladium to a thickness of approximately 250 ̊. The above specimens were attached to an acrylic plate with glue tape. Subsequently, half of the plate bottom was cut with a diamond disc and vertically divided into two pieces with a chisel and hammer.
Finally, the cut face of each specimen was examined with a scanning electron microscope (JXA-840; JEOL, Tokyo, Japan) at 5-Io kV.

\section{Results}

\section{Flow cytometry}

The flow cytometric study showed that the platelet cells in the PRP gel were strongly positive for $\mathrm{CD}_{4} \mathrm{I}$ when incubated with CD4I-PE (Figs I-3).

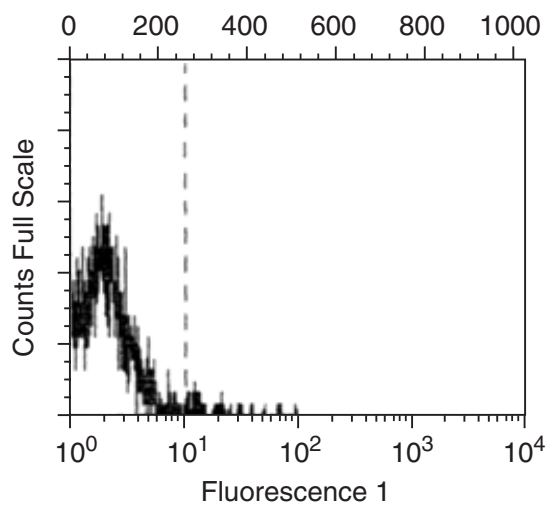

Fig. I. Negative control.

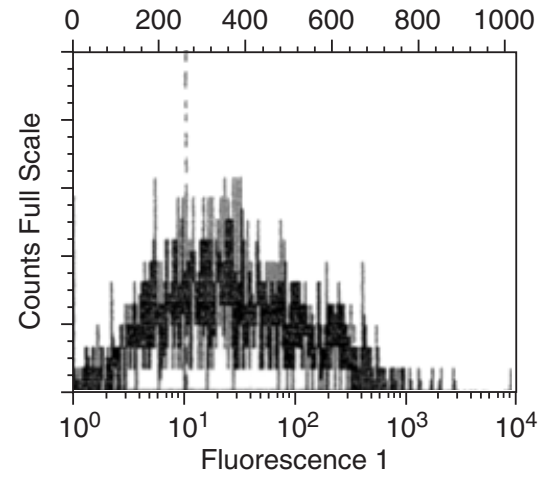

Fig. 2. HLA-II positive.

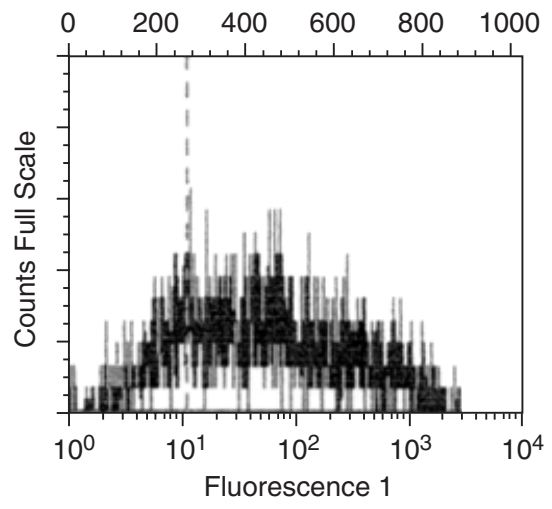

Fig. 3. CD-4I positive. 


\section{TEM}

Ultrastructural analysis by TEM confirmed that the cell component of the PRP gel was constituted by platelet cells, visualizing the following: dense, rounded and elongated granules in the cytoplasm, surrounded by membrane; small, ovoid mitochondria; peripheral microtubule and microfibril bundles; rough endoplasmic reticulum of variable morphology and a small proportion of free ribosomes; and some siderosomes (Figs 4 and 5).

\section{SEM}

The SEM study yielded clear images of the elements that constituted the PRP gel, which had a breadcrumb-like appearance (Fig. 6). It contained randomly arranged fibrillar elements, of homogeneous thickness throughout their length, with platelet cell elements arranged among them (Fig. 7). The platelets did not show the typical morphology of their resting state but rather morphologic signs of their activation: ovoid platelet cell elements with exocytosis phenomena, evidenced by the presence of vesicular formations on the cell surface (Fig. 8). No binding elements were observed between the cells and filaments in the matrix.

\section{Discussion}

This study used SEM and TEM techniques to characterize a PRP gel produced in situ during the therapeutic procedure. Many different techniques have been proposed to obtain a PRP concentrate (Marx et al. I998; Anitua I999; De Obarrio et al. 2000; Landesberg et al. 2000; Rosenberg \& Torosian 2000; Lozada et al. 200I; Shanaman et al. 200I; Sonnleitner et al. 2000; Vanassche \& Defranq 200I; Gonshor 2002; Tischler 2002). The method of Anitua (1999), one of the most frequently adopted protocols, was employed in the present study.

Although the techniques to obtain PRP have been widely described and debated (Marx et al. I998, 200I; Landesberg et al. 2000; Appel et al. 2002; Tozum \& Demiralp 2003; Weibrich et al. 2003a, 2003b), limited information is available on the morphological ultrastructure of PRP gels. The literature has described how molecular factors derived from the gel may influence

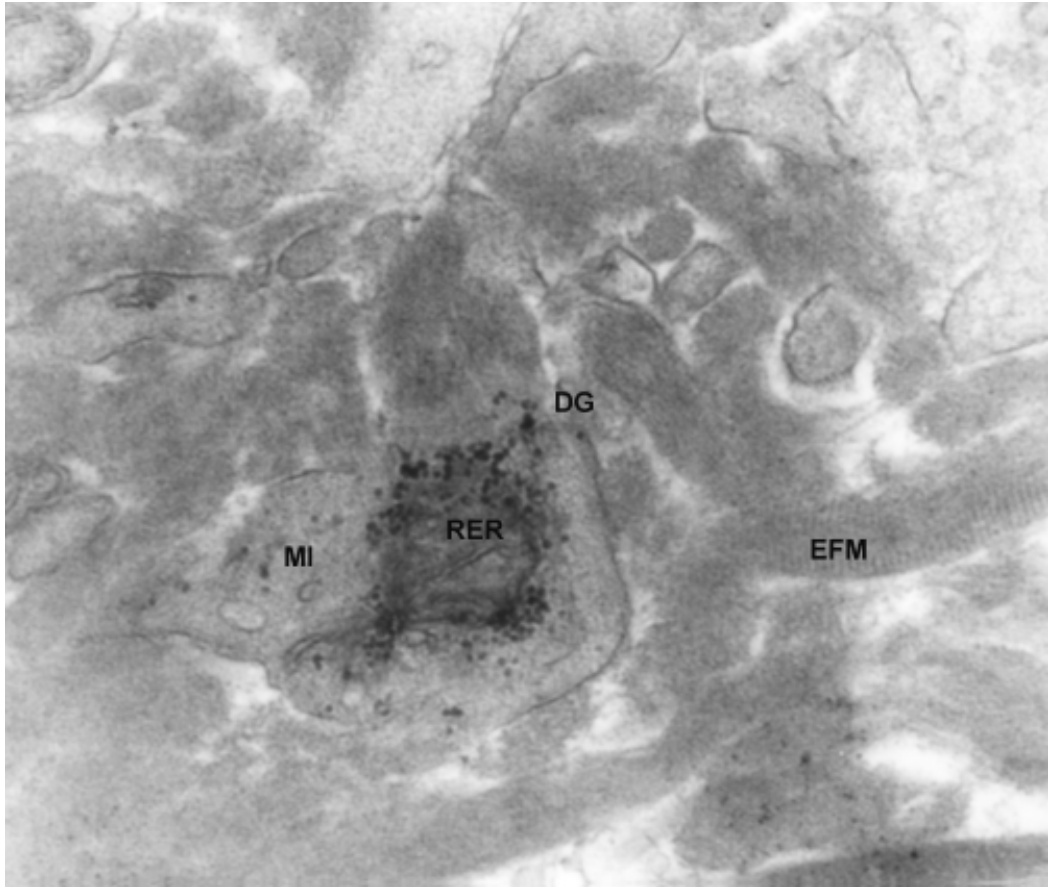

Fig. 4. Transmission electron microscopic image of human platelet-rich plasma. Platelet cells can be observed that contain dense granules (DG), mitochondria (MI) and microtubules, rough endoplasmic reticulum (RER) with ribosomes, siderosomes and section of the extracellular fibrin matrix (EFM).

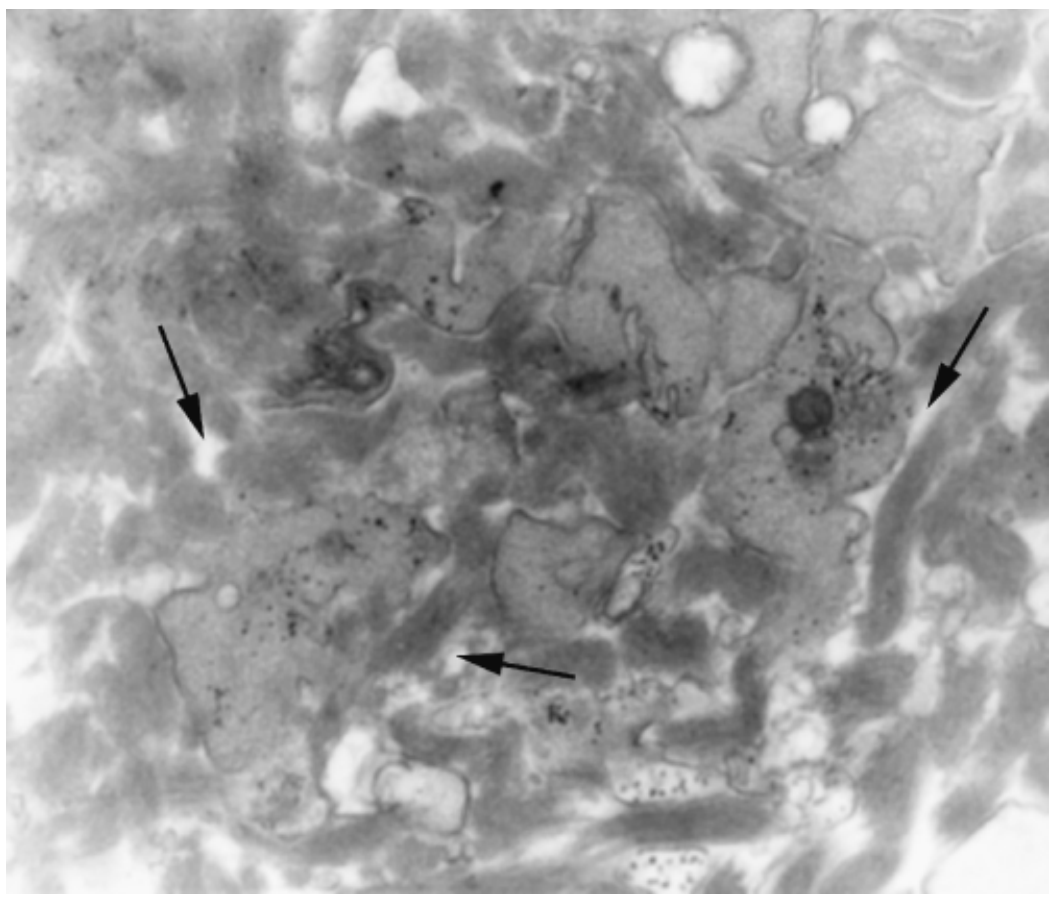

Fig. 5. Transmission electron microscopic image of human platelet-rich plasma. No physical relationship could be observed between the platelet cells and extracellular fibers (arrows showing spaces). The cells appear trapped in the fibrin matrix as if by a filter.

bone remodeling and regeneration of oral structures (Aghaloo et al. 2002; Carlson \& Roach 2002; Fürst 2003a, 2003b; Kawase 2003; Zechner et al. 2003; Wiltfang 2004).
Our flow cytometric study showed that the most of cells in the PRP gel were platelet cells. Flow cytometry is a simple laboratory technique with multiple uses, including the identification and quantifica- 


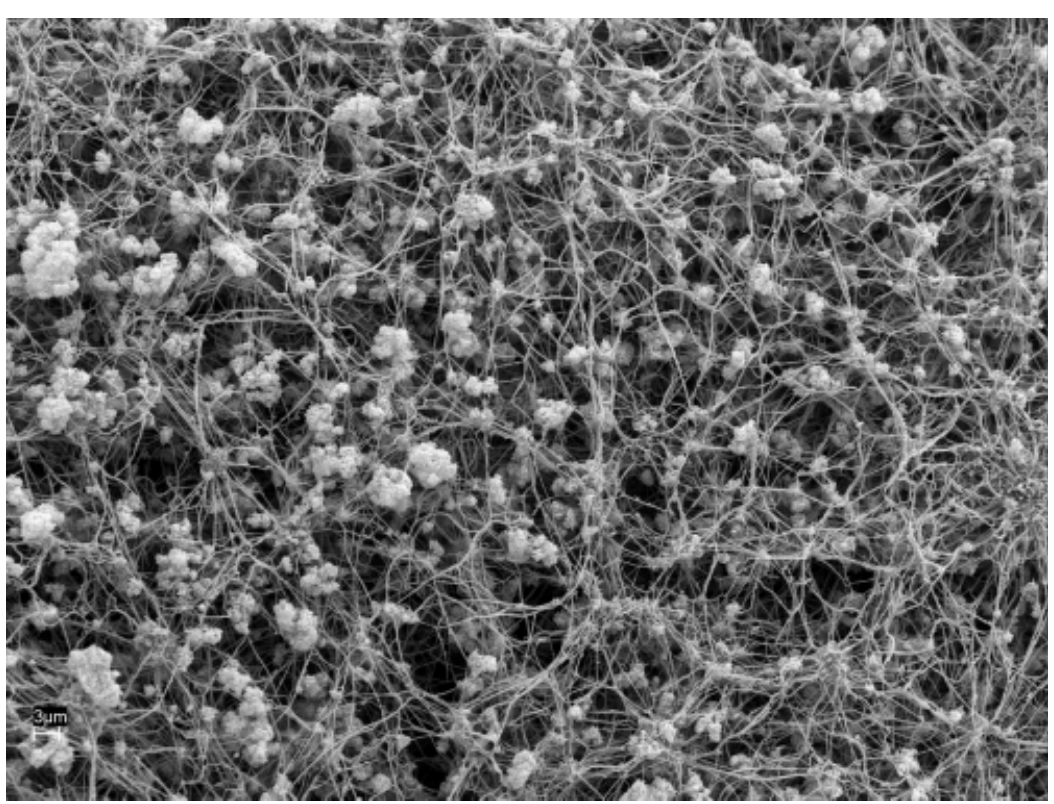

Fig. 6. Scanning electron microscopy of human platelet-rich plasma. A matrix can be observed of bread crumblike appearance, comprising randomly arranged fibrillar elements and platelet cells.

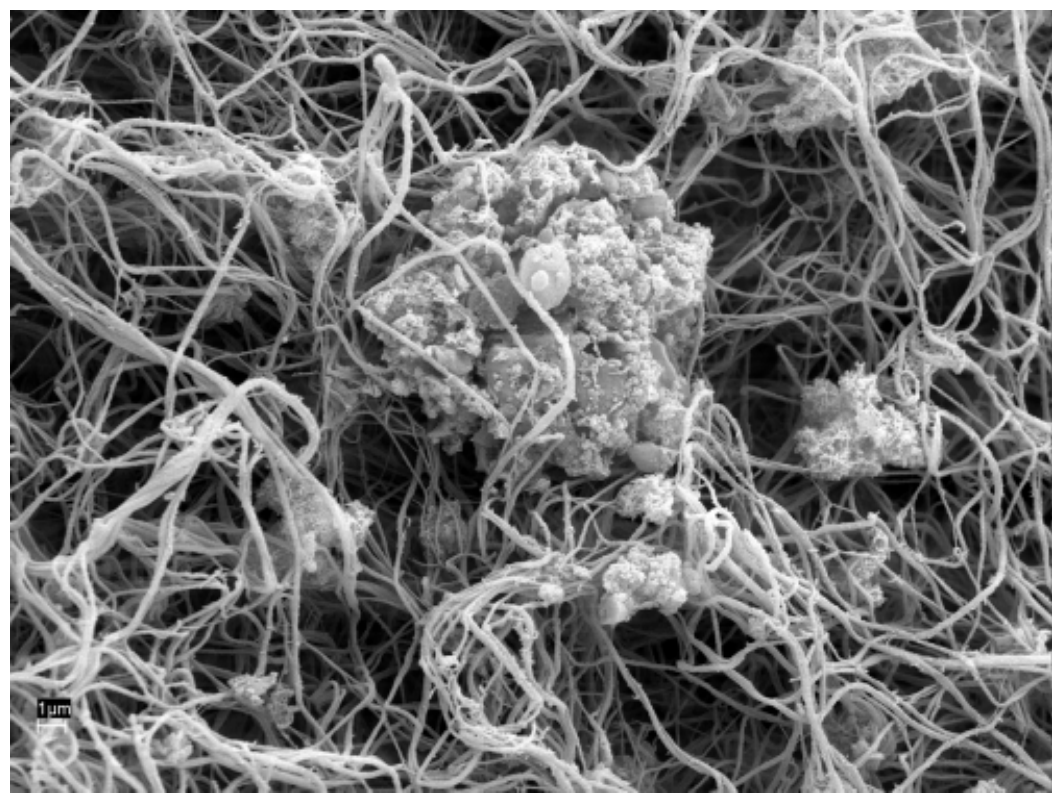

Fig. 7. Scanning electron microscopy of human platelet-rich plasma. Multiple platelet cell elements can be observed, forming a cell conglomerate trapped among fibrillar elements (fibrin). The platelet activation was illustrated by these cells, via their spherical-ovoid morphology and presence of exocytic vesicles.

tion of different cell populations within the same sample by the detection of specific monoclonal antibodies. This technique has been widely used by different authors in research on cell-based diseases (Morita et al. 1998; Thomas et al. 2002/ and, more specifically, in human and animal studies of platelets and other blood cells (Leytin et al. 1996; Michelson 2000; Matyus et al. 200I; Pichler et al. 2002; Chapman et al. 2003; Moritz et al. 2003).
The microscopic images obtained clearly demonstrate that the PRP gel is composed of fibrillar and cellular (essentially platelet cells) elements that are essential for the soft/hard tissue regeneration. Nonetheless, it has been shown the biologic effect of PRP is largely, contributed by the variety of growth factors that it possesses (e.g. PDGF, TGF- $\beta$, IGF, etc.) (Bennett \& Schultz I993a, I993b; Okuda et al. 2003). The TEM study revealed a wide filamentous network with striations, reminiscent of descriptions of fibrin in blood clots (Diaz-Flores et al. I974). It is possible that these filaments are involved in directing osteogenic cell movements during the bone generation process. Moreover, the fibers that make up this biological mesh are randomly arranged with no given orientation, indicating that a pre-determined arrangement does not appear to be essential for the migration and subsequent bone growth.

Therefore, the particular structure of PRP gel described here may enhance tissue regeneration, via its ability of carrying undifferentiated mesenchymal cells. Kawase et al. (2003) studied the action of PRP in different cell cultures and suggested that a fibrin clot in combination with growth factors can promote tissue regeneration in situations of periodontal damage. Furthermore, Anitua (2004) described platelets as cell elements capable of participating in tissue regeneration because of their high content of proteins that can enhance this process, especially growth factors.

On the other hand, no physical binding was found between the fibers and the trapped platelet elements, suggesting that the extensive network of filaments of the gel may act as a filter for the cell elements within it. This appears inconsistent with the known presence in these small nonerythrocyte cells of membrane glycoproteins responsible for establishing molecular bonds between the platelets and fibrillar elements. Nonetheless, it is agreed that one end of glycoproteín Gprb-IX is bound to the cytoskeleton with filamin molecules and the other acts as a receptor for two blood-clotting proteins (Coller 1990; Kieffer \& Phillips I990; Godet et al. I995). In addition, the platelet complex GpIIb-IIIa is able to bind with fibrinogen, producing the cross-linking of platelet into an aggregate (Hawiger et al. 1978; Leytin et al. 1996), and can then act as main receptor for platelet adhesion to inert surfaces of glass, titanium, and different biomaterials (Broberg et al. 2002).

With this background, it would be reasonable to assume molecular interactions occurred between fibrillar and cellular elements of the gel. Although they do not produce complex binding structures such as those described for cell-cell interactions, which are visible with SEM and TEM (Bloom et al. I994). 


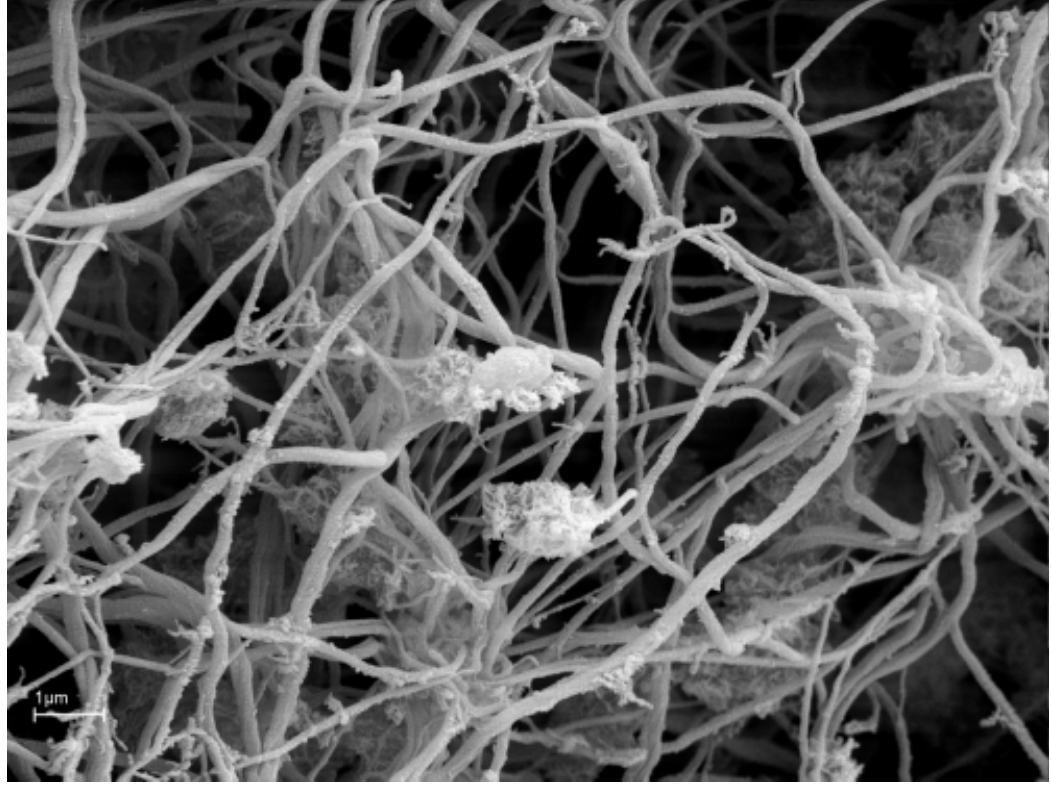

Fig. 8. Scanning electron microscopy of human platelet-rich plasma. Platelet cell elements can be observed trapped among fibrillar elements (filter-type trapping).

Taken together, the above results indicate the formation in vitro of a biological matrix that allows not only osteogenic cell migration but also the trapping of platelet elements that may induce proliferation and cell growth.

The SEM images showed a lumpy, breadcrumb-like surface of the gel at low magnification. At higher magnification, these lumps were seen to be composed of clumps of platelet cells, with exocytic vesicles on their surface that have been related to platelet activation mechanisms (Rotllan et al. I993). We believe this ob-

\section{References}

Aghaloo, T.L., Moy, P.K. \& Freymiller, E.G. (2002) Investigation of platelet-rich plasma in rabbit cranial defects: a pilot study. Journal of Oral and Maxillofacial Surgery 6o: I I76-I I8I.

Anitua, E. (I999) Plasma rich in growth factors: preliminary results of use in the preparation of future sites for implants. International Journal of Oral e) Maxillofacial Implants I4: 529-535.

Anitua, E. (200I) The use of plasma-rich growth factors (PRGF) in oral surgery. Practical Procedures in Aesthetic Dentistry I3: 487-493.

Anitua, E., Andia, I., Ardanza, B., Nurden, P. \& Nurden, A.T. (2004) Autologous platelets as a source of proteins for healing and tissue regeneration. Thrombosis and Haemostasis 9r: 4-I 5 .

Appel, T.R., Pötzsch, B., Müller, J., von Lindern, J-J., Bergé, S.J. \& Reich, R.H. (2002) Comparison of three different preparations of platelet concentrates for growth factor enrichment. Clinical Oral Implants Research I3: 522-528. servation to be of great interest, because it demonstrates that platelet activation is possible not only during the formation of a blood clot in vivo but also in a blood clot formed in vitro.

Further studies to characterize the PRP gels used in patients are warranted to establish the morphological and molecular mechanisms of the induced oral osteogenesis, the end-point of numerous procedures in oral and maxillofacial surgery. The ability to develop artificial clots and vary their fibrillar and cellular composition by means of molecular biology and tissue engineering would allow their use as a carrier in novel genetic therapies for the oral cavity.

\section{Acknowledgement: The authors} would like to thank Dr Rodrigo Neiva for his help in the management of the photos. This study was partially supported by the Investigation Planning of the University of Granada. The authors do not have any financial interests, either directly or indirectly, in the products listed in the study.

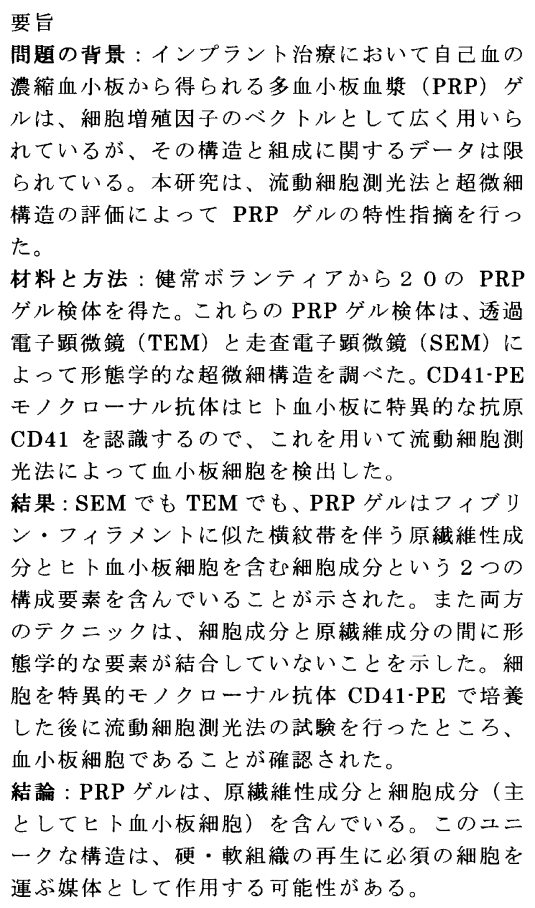

Arpornmaeklong, R., Kochel, M., Depprich, R., Kübler, N.R. \& Würzler, K.K. (2004) Influence of platelet-rich plasma (PRP) on osteogenic differentiation of rat bone marrow stromal cells. An in vitro study. International Journal of Oral and Maxillofacial Surgery 33: 60-70.

Bennett, N.T. \& Schultz, G.S. (I993a) Growth factors and wound healing: part I. Biochemical properties of growth factors and their receptors. American Journal of Surgery 165: 728-37.

Bennett, N.T. \& Schultz, G.S. (I993b) Growth factors and wound healing: part II. Role in normal and chronic wound healing. American Journal of Surgery I 66: 74-8 I.

Bloom, S., Holmstrup, P. \& Dabelsteen, E. (1994) A comparison of the effect of epidermal growth factor, platelet-derived growth factor, and fibroblast growth factor on rat periodontal ligament fibroblast-like cells DNA synthesis and morphology. Journal of Periodontology 65: 373-378.
Broberg, M., Eriksson, C. \& Nygren, H. (2002) $\mathrm{Gp \Pi b} / \mathrm{III}$ is the main receptor for initial platelet adhesion to glass and titanium surfaces in contact with whole blood. Journal of Laboratory and Clinical Medicine I39: I63-I72.

Carlson, N.E. \& Roach, R.B. Jr (2002) Plateletrich plasma: clinical applications in dentistry. Journal of the American Dental Association I33: I383-I386.

Chapman, E.S., Sorette, M., Hetherington, E., Zelmanovic, D., Kling, G., Dugailliez, J., Pujol-Moix, N. \& Okrongly, D. (2003) A rapid, automated flow cytometric method to measure activated degranulated platelets by density determination. Thrombosis and Haemostasis 89: 1004-IOI5.

Choi, B.H., Im, C.J., Huh, J.Y., Suh, J.J. \& Lee, S.H. (2004) Effect of platelet-rich plasma on bone regeneration in autogenous bone graft. International Journal of Oral and Maxillofacial Surgery 33: $56-59$. 
Coller, B.S. (I990) Platelets and thrombolytic therapy. New England Journal of Medicine 322: 33-42.

Della Valle, A., Sammartino, G., Marenzi, G., Tia, M., Espedito di Lauro, A., Ferrari, F. \& Lo Muzio, L. (2003) Prevention of postoperative bleeding in anticoagulated patients undergoing oral surgery: use of platelet-rich plasma gel. Journal of Oral and Maxillofacial Surgery 6r: I 275-I 278.

De Obarrio, J.J., Arauz-Dutari, J.I., Chamberlain, T.M. \& Croston, A. (2000) The use of autologous growth factors in periodontal surgical therapy: platelet gel biotechnology-case reports. International Journal of Periodontics and Restorative Dentistry 20: 486-497.

Diaz-Flores, L., Ortiz-Urdiain, G. \& González-Fernández, A. (I974) Ultraestructura del Sinoviosarcoma: estirpes celulares. Revista Ibys 32: I.

Fennis, J.P.M., Stoelinga, P.J.W. \& Jansen, J.A. (2004) Mandibular reconstruction: a histological and histomorphometric study on the use of autogenous scaffolds, particulate cortico-cancellous bone grafts and platelet-rich plasma in goats. International Journal of Oral and Maxillofacial Surgery 33: 48-55.

Fernández, J.E., Prados, J., Melguizo, C., Arena, N., Malavasi, F., Álvarez, L. \& Aránega, A. (I998) Characterization of a new embryonal rhabdomyosarcoma cell line, RMS-GR. Japan Journal Cancer Research 89: 525-532.

Froum, S.J., Wallace, S.S., Tarnow, D.P. \& Cho, S. (2002) Effect of platelet-rich plasma on bone growth and osseointegration in human maxillary sinus grafts: three bilateral case reports. International Journal of Periodontics and Restorative Dentistry 22: 45-53.

Fürst, G., Gruber, R., Tangl, S., Sanroman, F. \& Watzek, G. (2003b) Enhanced bone-to-implant contact bye platelet-released growth factors in mandibular cortical bone: a histomorphometric study in minipigs. International Journal of Oral や) Maxillofacial Implants I 8: 685-690.

Fürst, G., Gruber, R., Tangl, S., Zechner, W., Haas, R., Mailath, G., Sanroman, F. \& Watzek, G. (2003a) Sinus grafting with autogenous plateletrich plasma and bovine hidroxyapatite. A histomorphometric study in minipigs. Clinical Oral Implants Research 14: 500-508.

Godet, G., Canessa, R., Arock, M., Baron, J.F., Kieffer, E. \& Viars, P. (I995) Effects of plateletrich plasma on hemostasis and transfusion requirement in vascular surgery. Annales Françaises D'Anesthesie et de Reanimation I4: 265-270.

Gonshor, A. (2002) Technique for producing platelet-rich plasma and platelet concentrate: background and process. International Journal of Periodontics and Restorative Dentistry 22: 547-557.

Hawiger, J., Hammond, D.K., Timmons, S. \& Budzynski, A.Z. (I978) Interaction of human fibrinogen with staphylococci: presence of a binding region on normal and abnormal fibrinogen variants and fibrinogen derivatives. Blood $5 \mathbf{I}$ : 799-8I 2.

Jakse, N., Tangl, S., Gilli, R., Berghold, A., Lorenzoni, M., Eskici, A., Haas, R. \& Pertl, C. (2003) Influence of PRP on autogenous sinus grafts. An experimental study on sheep. Clinical Oral Implants Research I4: 578-583.

Kawase, T., Okuda, K., Wolff, L.F. \& Yoshie, H. (2003) Platelet-rich plasma-derived fibrin clot formation stimulates collagen synthesis in periodontal ligament and osteoblastic cells in vitro. Journal of Periodontology 74: 858-864.

Kieffer, N. \& Phillips, D.R. (I990) Platelet membrane glycoproteins: functions in cellular interactions. Annual Review of Cell Biology 6: 329-357.

Landesberg, R., Roy, M. \& Glickman, R.S. (2000) Quantification of growth factor levels using a simplified method of platelet-rich plasma gel preparation. Journal of Oral and Maxillofacial Surgery 58: 297-300; discussion 300-30I.

Lekovic, V., Camargo, P.M., Weinlander, M., Vasilic, N., Aleksic, Z. \& Barrie Kenney, E. (2003) Effectiveness of a combination of platelet-rich plasma, bovine porous bone mineral and guided tissue regeneration in the treatment of mandibular grade II molar furcations in humans. Journal of Clinical Periodontology 30: 746-75 I.

Lekovic, V., Camargo, P.M., Weinlaender, M., Vasilic, N. \& Barrie Kenney, E. (2002) Comparison of platelet-rich plasma, bovine porous bone mineral and guided tissue regeneration versus platelet-rich plasma and bovine porous bone mineral in the treatment of intrabony defects: a reentry study. Journal of Periodontology 73: I98-205.

Leytin, V., Shapiro, H., Novikov, I. \& Radnay, J. (I996) Flow cytometric analysis of the platelet surface area and surface density of glycoprotein Ilb-IIIa of unactivated human platelets of various sizes. Biochemical and Biophysical Research Community 226: 94-Ioo.

Lozada, J.L., Caplanis, N., Proussaefs, P., Willardsen, J. \& Kammeyer, G. (200I) Platelet-rich plasma application in sinus graft surgery: part I Background and processing techniques. Journal of Oral Implantology 27: 38-42.

Maiorana, C., Sommariva, L., Brivio, P., Sigurta, D. \& Santoro, F. (2003) Maxillary sinus augmentation with anorganic bovine bone (Bio-Oss) and autologous platelet-rich plasma: preliminary clinical and histologic evaluations. International Journal of Periodontics and Restorative Dentistry 23 : 227-235.

Marx, R.E. (200I) Platelet-rich plasma (PRP): what is PRP and what is not PRP? Implant Dentistry IO: 225-228.

Marx, R.E., Carlson, E.R., Eichstaedt, R.M., Schimmele, S.R., Strauss, J.E. \& Georgeff, K.R. (I998) Platelet-rich plasma: growth factor enhancement for bone grafts. Oral Surgery Oral Medicine Oral Pathology Oral Radiology and Endodontics 85: 638-646.

Matyus, L., Bene, L., Harsfalvi, J., Alvarez, M.V., Gonzalez-Rodriguez, J., Jenei, A., Muszbek, L. \& Damjanovich, S. (200I) Organization of the glycoprotein (GP) IIb/IIIa heterodimer on resting human platelets studied by flow cytometric energy transfer. Journal of Photochemistry and Photobiology: B 65: 47-58.

Michelson, A.D. (2000) Flow cytometric analysis of platelets. Vox Sanguinis 78 (Suppl. 2): I37-I42.

Morita, Y., Yamamura, M., Kawashima, M., Harada, S., Tsuji, K., Shibuya, K., Maruyama, K. \&
Makino, H. (I998) Flow cytometric single-cell analysis of cytokine production by $\mathrm{CD}_{4}+\mathrm{T}$ cells in synovial tissue and peripheral blood from patients with rheumatoid arthritis. Arthritis and Rheumatism 4I: I669-I676.

Moritz, A., Walcheck, B.K. \& Weiss, D.J. (2003) Flow cytometric detection of activated platelets in the dog. Veterinary Clinical Pathology 32: 6-I2.

Okuda, K., Kawase, T., Momose, M., Murata, M., Saito, Y., Suzuki, H., Wolff, L.F. \& Yoshie, H. (2003) Platelet-rich plasma contains high levels of platelet-derived growth factor and transforming growth factor-beta and modulates the proliferation of periodontally related cells in vitro. Journal of Periodontology 74: 849-857.

Pichler, J., Printz, D., Scharner, D., Trbojevic, D., Siekmann, J. \& Fritsch, G. (2002) Improved flow cytometric method to enumerate residual cells: minimal linear detection limits for platelets, erythrocytes, and leukocytes. Cytometry 50: 23 I-237.

Roldán, J.C., Jepsen, S., Miller, J., Freitag, S., Rueger, D.C., Açil, Y. \& Terheyden, H. (2004) Bone formation in the presence of platelet-rich plasma vs. morphogenetic protein-7. Bone 34: 80-90.

Rosenberg, E.S. \& Torosian, J. (2000) Sinus grafting using platelet-rich plasma-initial case presentation. Practical Periodontics in Aesthetic Dentistry 12: 843-850; quiz 852.

Rotllan, E., Escolar, G., Ordinas, A. \& Bastida, E. (I993) Effect of PAF (platelet-activating factor) on hemostasis. Studies on endothelial cells and platelets. Blood 38: I I 5-I I9.

Sánchez, A.R., Sheridan, P.J. \& Kupp, L.I. (2003) Is platelet-rich plasma the perfect enhancement factor? A current review. International Journal of Oral e) Maxillofacial Implants r 8: 93-IO3.

Schmitz, J.P. \& Hollinger, J.O. (200I) The biology of platelet-rich plasma. Journal of Oral and Maxillofacial Surgery 59: I I I9-I I I I.

Shanaman, R., Filstein, M.R. \& Danesh-Meyer, M.J. (200I) Localized ridge augmentation using GBR and platelet-rich plasma: case reports. International Journal of Periodontics and Restorative Dentistry 2r: 345-355.

Soffer, E., Ouhayoun, J.P. \& Anagnostou, F. (2003) Fibrin sealants and platelet preparations in bone periodontal healing. Oral Surgery Oral Medicine Oral Pathology Oral Radiology and Endodontics 95: $52 \mathrm{I}-528$.

Sonnleitner, D., Huemer, P. \& Sullivan, D.Y. (2000) A simplified technique for producing platelet-rich plasma and platelet concentrate for intraoral bone grafting techniques: a technical note. International Journal of Oral «) Maxillofacial Implants I5: 879-882.

Thomas, R.A., Krishan, A. \& Brochu, M. (2002) High resolution flow cytometric analysis of electronic nuclear volume and DNA content in nor$\mathrm{mal}$ and abnormal human tissue. Methods in Cell Science 24: I I-I 8 .

Thorn, J.J., Sorensen, U., Weis-Fogh, M. \& Andersen, M. (2004) Autologous fibrin glue with growth factors in reconstructive maxillofacial surgery. International Journal of Oral and Maxillofacial Surgery 33: 95-Ioo.

Tischler, M. (2002) Platelet rich plasma. The use of autologous growth factors to enhance bone and 
soft tissue grafts. New York State Dentistry Journal 68: 22-24.

Tozum, T.F. \& Demiralp, B. (2003) Platelet-rich plasma: a promising innovation in dentistry. Journal of Canadian Dental Association 69: 664.

Vanassche, B. \& Defrancq, J. (200I) Use of PRP (Platelet Rich Plasma) in bone volume augmentation). Revue Belge de Medecene Dentaire 56: I $25-\mathrm{I} 33$.

Weibrich, G., Kleis, W.K.G., Hafner, G., Hitzler, W.E. \& Wagner, W. (2003a) Comparison of platelet, leucocyte and growth factor levels in point-ofcare platelet-enriched plasma, prepared using a modified Curasan kit, with preparations received from a local blood bank. Clinical Oral Implants Research I4: $357-362$.
Weibrich, G., Kleis, W.K.G., Buch, R., Hitzler, W.E. \& Hafner, G. (2003b) The Harvest Smart Prep ${ }^{\text {TM }}$ system versus the Friadent-Schütze platelet-rich plasma kit. Comparison of a semiautomatic method with a more complex method for the preparation of platelet concentrates. Clinical Oral Implants Research I4: 233-239.

Weibrich, G., Hansen, T., Kleis, W., Buch, R. \& Hitzler, W.E. (2004) Effect of platelet concentration in platelet-rich plasma on peri-implant bone regeneration. Bone 34: 665-67I.

Wiltfang, J., Kloss, F.R., Kessler, P., Nkenke, E., Schultze-Mosgau, S., Zimmerman, R. \& Schlegel, K.A. (2004) Effects of platelet-rich plasma on bone healing in combination with autogenous bone and bone substitutes in critical-size defects. Clinical Oral Implants Research I5: I 87-I93.

Wiltfang, J., Schlegel, K.A., Schultze-Mosgau, S., Nkenke, E., Zimmermann, R. \& Kessler, P. (2003) Sinus floor augmentation with beta-tricalciumphosphate (beta-TCP): does platelet-rich plasma promote its osseous integration and degradation? Clinical Oral Implants Research I4: 2I3-2I 8.

Zechner, W., Tangl, S., Tepper, G., Fürst, G., Bernhart, T., Haas, R., Mailath, G. \& Watzek, G. (2003) Influence of platelet-rich plasma on osseous healing dental implants: a histologic and histomorphometric study in minipigs. International Journal of Oral et Maxillofacial Implants I8: I 5-22. 